\title{
Missing in action and lost in thought: a grassroots implementation of genre pedagogy by practitioner researchers in an English language classroom for adults
}

Desaparecido em ação e perdido em pensamentos: uma implementação de base da pedagogia de gênero por pesquisadores profissionais em uma sala de aula de inglês para adultos.

\section{Andrew Glencairn Scott}

The University of Queensland - Queensland - Austrália

\section{Tanja Hafenstein}

The University of Queensland - Queensland - Austrália

\begin{abstract}
This paper reports on the grass roots adoption of a methodology for teaching reading and writing based on genre theory (Martin \& Rose, 2012; Rose \& Martin, 2012) in English for general purposes classes at an English language teaching (ELT) centre at an Australian university. We report on teachers' experiences on using genre pedagogy, informed and inspired by the Reading to Learn (R2L) program and genre pedagogy from the so-called 'Sydney School' (Martin \& Rose, 2007; Martin \& Rose, 2008; Rose \& Martin, 2012). We report on how we introduced elements of the R2L program into our lessons using a 'bottom up' approach with the view that individual teachers might find this useful for implementation of this methodology in their own contexts. We found that genre pedagogy can be adopted by teachers and implemented at the classroom level despite such challenges as teachers learning new classroom practices and reconciling differences with previous classroom practices.
\end{abstract}

\section{Introduction}

Teaching and learning writing in the English language classroom can present teachers with a range of challenges. One challenge at the planning stage is selecting appropriate examples of written texts and deciding upon classroom activities that enable learners to interact with and understand such texts. Written texts that are appropriate to both learners' future social practices (e.g. writing a report) and current language proficiency are an ideal choice. Similarly, activities that support learners to interact with and understand these written texts in a manner that aligns with learners' future social practices and current language proficiency are also appropriate. One way to proceed is for teachers to view written texts in terms of their purpose, such as that of the genre writing approach. (Christie and Martin, 1997; Cope and Kalantzis, 1993; Rose 2008, 2011; Rothery, 1994, 1996). For example, this would mean viewing an argumentative essay in terms of its purpose, as arguing for a point of view. When teachers and learners examine and co-create different types of text according to their purpose, this enables learners to clearly see the role they play in social practices. This can lead to greater understanding and more effective control as learners develop greater independence in their writing and begin to engage in the target social practices.

\subsection{Theoretical background}

In the so-called 'Sydney School' of genre pedagogy (Rose and Martin, 2012), genre is defined as a goal-oriented social process that develops through language in stages (Martin, 2009, p. 13). Examples of genres include a report, a story or a procedure. Several decades of action research have produced detailed studies of both genre and classroom practice. In this 
school of genre pedagogy, teaching and learning is viewed as a process of "guidance through interaction in the context of shared experience" (Martin, 1999, p. 126). In a classroom setting, this involves the teacher guiding learners to interact with written texts such as biographical recounts, expositions (i.e. arguing for a point of view) or descriptive reports. These are termed knowledge genres (Rose, 2020, p. 239) and more examples are given in Figure 1, below. Knowledge genres are often specified in a syllabus and selected by materials designers or teachers.

Teachers help learners to become aware of the social purposes of these knowledge genres, their organisation and their language features by negotiating meanings through classroom discourse. Teachers also achieve their lessons aims through a goal-oriented social process that develops through language in stages (Martin, 2009, p. 13). In other words, the language of teachers and learners in the classroom is also a type of genre, and these are termed curriculum genres (Rose, 2020, p. 239). Curriculum genres are multimodal, and involve language, body language, images and the other resources teachers use in their classroom practice to exchange knowledge with learners (Rose, 2020, p. 240). Examples from the Reading to Learn (R2L) program are Preparing for Reading and Joint Rewriting. More examples are given in Figure 1, below. We can summarise classroom practice using these terms as teachers guiding learners to interact with knowledge genres through curriculum genres in order for learners to gain greater control and work towards mastery of the knowledge genres.

In English for general purposes language courses for adults (sometimes called General English or GE), the goal is often to socialise learners into the English language community through giving them greater control of relevant genres. The knowledge genres in these courses are seemingly everyday and non-technical compared to, for example, English for Academic Purposes (EAP) courses. This results in different fields of activity and knowledge (Rose, 2017). GE knowledge genres might include writing an argumentative essay or a biographical recount. GE learners are also writing to a different audience to EAP learners, leading to differences in the relationships between writer and reader (i.e. the tenor of social relations) (Martin \& Rose, 2008, p.11). While an argument genre may appear across curriculums (e.g. GE and EAP), the intended audience will not be the same. For example, writing an essay for a popular magazine with a general readership in GE versus writing an essay for a lecturer in EAP will require variations in tenor.

Similarly, differences in essay topics (e.g. on medicine or business) will result in variations in the social activity (i.e. the field) (Martin \& Rose, 2008, p.11). Finally, a written essay versus a video essay will see changes in the role language is playing in managing the communication (i.e. mode) (Martin \& Rose, 2008, p.11). These differences in tenor, field and mode reflect variations in context; each situation has a different combination of relationships, social activity and the role language is required to play. Taken together, tenor, field and mode are called register variables because they vary systematically (Martin \& Rose, 2008, p.11). Different situations result in different configurations of register (e.g. tenor, field and mode), which also vary the patterns of meaning in a text (Martin \& Rose, 2008, p.11). These variables need to be considered when teaching writing in order to plan effective lessons and highlight salient features to our learners. Our GE syllabus consisted of knowledge genres from broad domains of social life, such as 'describing places' and 'life events' (see Figure 1 below). 


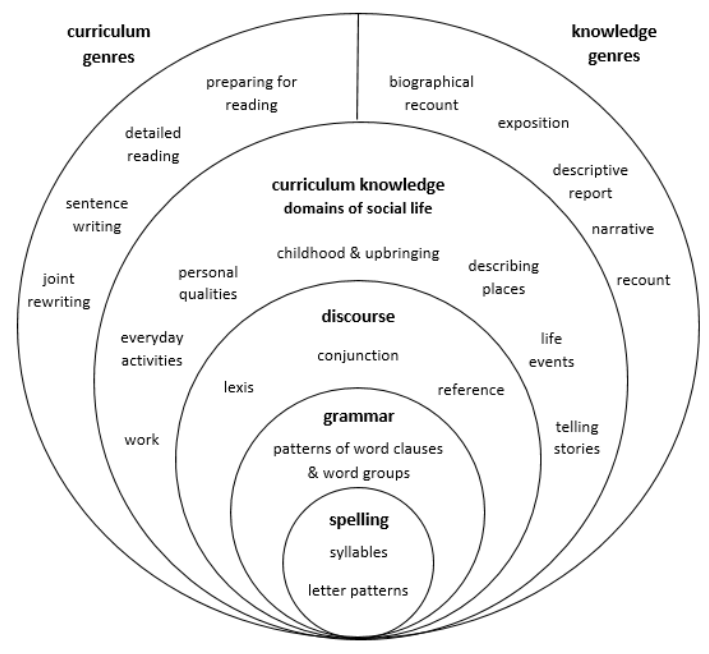

Figure 1: Language in context of social domains and genres (adapted from Rose, 2017, p.21 and Rose \& Martin, 2012, p. 130)

\subsection{An overview of knowledge genres and} curriculum genres

The classroom is also a social space where teachers use language to achieve goals in stages. From the perspective of genre pedagogy, interactions between teacher and learners enact relationships, classroom activities construe experience and language is used to construct and organise meanings as the lesson unfolds. In other words, classroom language use can be viewed as specialised curriculum genres with particular selections in register (Rose, 2020; Christie, 2002). These selections in register include 1) a curriculum register of knowledge and values and 2) a pedagogic register of a) pedagogic relations between teacher and learners, b) pedagogic activity of learning tasks and c) pedagogic modalities such as "spoken, written, visual and gestural modes of communication" (Rose, 2020, p. 240). Through action research and working closely with teachers over many years, curriculum genres have been carefully planned to ensure teachers can guide learners through interaction in the context of shared experience (Martin, 1999; 2012). These have been reported by Rose and Martin (2012) and developed into teacher education materials for the R2L program (Rose, 2018). In addition, videos of David Rose demonstrating these interactions in the classroom with explanations of the process are also available to teachers through the R2L program.

There are several key elements that distinguish R2L curriculum genres from other practices in the writing classroom. The most striking for the present authors was the assertive guidance of the teacher and carefully planned classroom language that pre-empts and therefore reduces the need to work contingently with learners' emerging language during writing by firstly discussing a writing model of a target knowledge genre in detail for deeper understanding. This contrasts with the more passive role communicative language teachers adopt in communicative classrooms during guided-discovery writing activities and group work. The carefully planned interactions as outlined in the R2L program allow teachers to skilfully guide learners though a written text to ensure that everyone in the class has understood it before then guiding and supporting the class to use the linguistic resources of the text to create another. These interactions are carefully described in Section 3 below.

\subsection{An overview of key curriculum genres}

Curriculum genres are "the multimodal genres of classroom practice, in which knowledge is exchanged between teacher and learners" (Rose, 2020, p. 239), first described by Christie (2002). These have been made accessible to teachers through the Reading to Learn (R2L) program (Rose, 2015, 2017, 2018; Rose \& Martin, 2012), which is both a genrebased pedagogy and a professional learning program (Rose, 2020, p. 236). In other words, curriculum genres are the various components that make up classroom practices and which are necessary for teachers to guide learners in understanding knowledge genres before attempting to write a similar text independently. This means learners must understand the purpose and organisation of a text and understand its particular language features. Knowledge of these components is passed to learners from the teacher through carefully planned interactions. The R2L program is a professional learning program which helps teachers to plan and use these important exchanges. This, in turn, allows teachers to develop learners' control over 
knowledge genres and participate in these social processes that involve written texts. For a detailed description of the program see Rose and Martin, 2012. Furthermore, through engaging with the training materials of the program, we identified curriculum genres that promised to be of particular use to our learners.

The R2L program contains five core curriculum genres: Preparing for Reading, Detailed Reading, Sentence Making, Joint Rewriting and Joint Construction with classroom work on whole texts, narrowing down to work on passages and sentences before returning to whole texts (see Figure 2 below). The key curriculum genres we identified as relevant to our learners are Preparing for Reading, Detailed Reading and Joint Rewriting. These were selected because we wanted to foreground work on short passages as this allowed us to work on spelling should it arise but focus primarily on grammar, discourse and register. While we carefully prepared learners to read, time limitations did not permit us to work with learners on the joint construction of whole texts. These key curriculum genres will now be defined and the lesson planning and classroom language described.

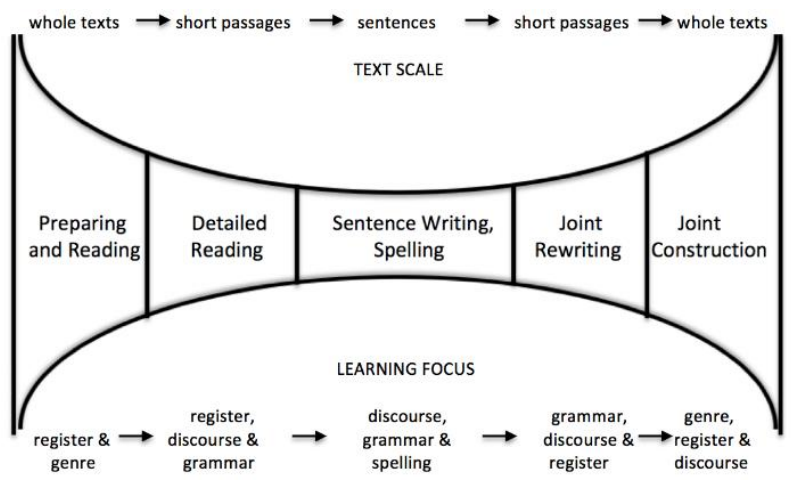

Figure 2: Sequence of curriculum genres in R2L methodology (adapted from Rose, 2017, p.14)

In brief, Preparing for Reading involves previewing the text by the teacher stating its purpose and giving a spoken summary of it. This provides support to learners and enables them to follow the meaning of the text when it is read allowed by the teacher. Before reading the text aloud, the teacher prepares learners by providing a summary of each sentence in language they can understand. After reading the sentence aloud, the teacher then supports learners to identify key words, phrases and language patterns which are then discussed and highlighted. This ensures that every learner develops a detailed understanding of the passage. Joint Rewriting involves the teacher supporting learners to write a new passage using the key words, phrases and language patterns that were identified and discussed in the Detailed Reading. Each of these curriculum genres involve careful analysis and preparation by the teacher to ensure that the lesson maintains an appropriate learning pace, thereby keeping learners engaged but not leaving anyone behind.

\subsection{Practitioner research}

Practitioner research is a broad term that includes practicing professionals, such as nurses, social workers and teachers, engaging in systematic enquiry into their own work practices. Teacher research can be defined as systematic self-study by teachers working individually or collaboratively to lead to realworld impact. It is also made public (Borg \& Sanchez, 2015a, p.1). Like all forms of research, it is systematic. The self-study element refers to the teacher examining their own work and context. The real-world impact could be realised in terms of informing teachers' beliefs, knowledge, skills or classroom practices, learners' beliefs, knowledge of performance, or its effect on the organisation more broadly (Borg \& Sanchez, 2015a, p.1). What distinguishes teacher research from reflective practice (Wallace, 1991) is that teacher research is shared with others by being made public. This defining feature means that teacher research can be critiqued, reviewed, replicated and developed as was the case for the present authors. This is in sharp contrast to private enquiry that, no matter how systematic, cannot make a contribution to field knowledge.

There are additional terms that are commonly associated with practitioner research in education. Action research (Burns, 2010, p.8) refers to cycles of planning, action, observation and reflection that are used to evaluate changes in practice. This methodology has been criticized by some researchers 
as it places action before understanding (Allwright \& Hanks, 2009). As an alternative, Exploratory Practice (EP) foregrounds understanding over action (Allwright \& Hanks, 2009). It also aims to be sustainable and views learners as practitioners of learning who can develop their knowledge by working with teachers. This allows them to investigate their own classroom behaviours during language lessons (Allwright \& Hanks, 2009). Classroom research is a broader term that focuses on the classroom and seeks to discover what occurs in the classroom setting (Allwright \& Bailey, 1991, p.2). It is clear that most teacher research is also classroom research. However, classroom research carried out by traditional researchers investigating the practices of others is not teacher research. By traditional researchers we mean 'outsider' researchers who do not teach in the context they are researching, e.g. academic researchers from a university.

Practitioner research can have a significant impact, ranging in scope from effects on an individual's practice to that of a whole organisation. It is important to bear this in mind if a researcher is going to influence practice. While individuals may be familiar with completing projects that investigate an aspect of their own workplace as part of professional development activities, practitioner research can offer greater, more wide-ranging benefits. In particular, practitioner research can extend and enhance understanding within a particular field, as the knowledge, experience and ideas of the professionals involved contributes to the quality and validity of the research through their efforts in identifying research areas, developing research questions and implementing changes to their professional practices (Barton, 2005, p. 33). In our case, we regularly reflect and work collaboratively to develop professional practices, share our research and practices in in-service workshops and seminars, and make this experience public in order to have a realworld impact in the TESOL community.

\subsection{Positive effects of practitioner research}

The involvement of practitioners and the foregrounding of the workplace and those stakeholders closely associated with it (e.g. learners and academic managers) can enable previously overlooked voices to become heard and valued. This, in turn, can create new metaphors and understandings based on comments by these stakeholders that emerge from their discussion of key issues. For example, in one practitioner research project a learner likened her fear of group work to "putting your hand into a pool of dark water and the thought that there might be a snake there" (Hamilton, 2006, p.15). As busy teachers, we can often miss a similar key issue like this from a learner or other stakeholder because we can be busy managing the lesson itself and therefore missing in the action of the classroom (adapted from Shulman cited by van Lier, 1994, p. 340). Engaging with the R2L program materials also often left our minds occupied with adopting this new methodology and lost in thought (van Lier, 1994, p. 340).

For us, planning, reflecting and discussing our $\mathrm{R} 2 \mathrm{~L}$ lessons together gave us a way to navigate our way through writing lessons and find a path through the tricky terrain of changing our classroom practices. Metaphors such as these can generate new perspectives and understandings that have implications for both the immediate (e.g. the classroom) and the wider context (the TESOL community). Although more traditional research may be able to uncover insights such as these, it is characteristic of practitioner researcher that immediate, local issues and concerns (such as the learner who feared group work or teachers adopting a new methodology) play a more central role in the research endeavour, which gives local stakeholders a voice.

Compiling the benefits of teacher research cited by language teaching professionals around the world, Borg and Sanchez (2015b, p. 189) give twentytwo benefits, listed in Table 1 below. These benefits have the potential to lead to lasting behavioural change if accompanied by changes to teachers' knowledge and beliefs. Teacher research has the capacity to facilitate 
these cognitive and behavioural changes (Borg and Sanchez, 2015b, p. 189).

Table 1: Benefits of teacher research

- Promotes collaboration among teachers

- Gives teachers insight into their own practices

- Promotes innovative solutions to teaching problems

- Extends teacher identities (to include teacheras-researcher)

- Creates a sense of achievement

- Boosts teachers' self-esteem

- Creates a problem-solving mindset

- Promotes more student-centred perspectives

- Encourages flexibility in teaching

- Raises teachers' awareness of ingrained habits

- Narrows the gap between theory and practice

- Promotes reflective skills

- Creates a sense of community

- Makes teachers more open to feedback

- Increases teachers' knowledge

- Develops 'adaptive expertise'

- Enhances teachers' repertoires

- Enhances professional autonomy

- Improves research skills

- Increases teacher motivation

- Leads to positive changes in what teachers do

- Creates positive attitudes to professional development

\subsection{Issues associated with practitioner} research

There are several ethical issues to consider. The first is that practitioner researchers have two relationships with other stakeholders. A teacher has a professional relationship with colleagues and learners, managed and maintained by professional regulations and guidelines that have been developed by professional organisations, regulatory bodies and employers. These guidelines regulate behaviour and make the expectations of the profession clear. They cover areas such as workplace communication, the boundaries between professional and personal relationships and the teacher's duty of care.

Practitioner researchers also have responsibilities as researchers. These responsibilities are outlined by professional associations and by organisations that fund research, such as universities. For example, the British Association of Applied Linguists (2016) provides recommendations on good practice regarding the ethical behaviour of researchers. Both sets of responsibilities need to be considered by practitioner researchers when planning for and conducting their research. Many practitioner researchers will consider themselves practitioners first and researchers second, and they might therefore order their priorities accordingly. The responsibilities of the researcher come in to play when dealing with data, for example anonymizing data and storing it securely.

It is possible to conceive of scenarios in which these two sets of ethical considerations come into conflict. The researcher might be tempted to place their own research interests above the best interests of other stakeholders. For example, a teacher investigating pronunciation development in learners might be tempted to administer a particular technique because it is relevant to their research rather than because of its efficacy. While such extreme conflicts may be uncommon, practitioner researchers do need to consider if and when it is ethical to work on their projects. Because they are investigating their own working environments, the research can be considered work-related, and, as a professional development activity, there might be time allocated to it as part of the practitioner's terms and conditions of work. It might be impossible for a practitioner to complete a research project unless time is devoted to it while at work. The practitioner researcher must therefore consider whether, and decide when, it is appropriate to work on research projects during their paid working hours without neglecting their workplace duties.

Another ethical concern relates to sharing the benefits of the research with stakeholders. By making the results public, findings from practitioner research are more readily shared than those of reflective practice. This might occur at a conference or professional development meeting, in which case the research is shared with other practitioners. It is perhaps more challenging to share the results with other stakeholders involved in the research project who have contributed their time to its undertaking. For example, a teacher's project might be concerned with learners' writing development and involve the learners allowing their work to be analysed. They might also give their 
time to be interviewed about their writing to discover their views on its development. By the time the interviews are completed and the analysis carried out and written up, the teacher may no longer be working with these same learners. Depending on the context, they may have moved on to another class or, if learning English overseas, returned to their own countries, making it difficult to share the results. For some practitioner researchers, the benefits will be passed on to future learners, through sharing their findings with other practitioners. Alternative models involve learner participation in the study itself. For example, Exploratory Practice (Allwright \& Hanks, 2009) might involve learners in data collection, bringing them into the research project (Borg \& Sanchez, 2015a, p5).

In addition to finding an appropriate balance between completing a research project and meeting work requirements and responsibilities, practitioners also need to allow sufficient time for thought and the research process. Professionals have busy working lives and starting a research project is likely to add to this workload. As van Lier notes, adapting the words of Shulman (1987, p. 478), "[p]ractitioners tend to be missing in action rather than lost in thought" (1994, p. 340). This is something we strongly recognise as practitioners and is is an issue that we have referred to earlier in this article and in the title of this paper. Teachers are invariably kept busy planning and teaching lessons and the extra work of a research project is not always manageable. This has led some researchers to call for teacher research to be made more sustainable (Allwright, 1997). This means teachers designing projects that are feasible and manageable in terms of their working conditions, knowledge, and skills (Borg \& Sanchez, 2015a, p. 3). For example, a project that required a significant time commitment in addition to the working week would not be feasible. Alternatively, a project that required the collection of large amounts of quantitative data followed by complex statistical analyses would not be manageable either (Borg \& Sanchez, 2015a, p. 3). While practitioner researchers are experts in their own contexts with access to understandings and practices that could prove difficult for traditional researchers, do not necessarily possess research expertise. The sustainability of a research project must be considered in the planning stage to ensure practitioner researchers are aware of the commitment, skills and knowledge required to successfully complete it.

However, it cannot be assumed that teacher research will always occur or that it will be viewed positively by other researchers. As van Lier observes, “... reflecting and researching teachers may meet with resistance or lack of comprehension, perhaps even ridicule and active sabotage, from peers and superiors, as well as from academics who feel their turf is being invaded by unauthorized invaders" (1994, p. 340). Traditionally there has been a clear divide between research and practice, with university-based researchers and scholars creating the theories that professionals apply in practice (Schön, 1983, p. 36). This view may still be held by some stakeholders who see the practitioner's role as one of practice with no scope for research.

\section{Methodology \\ 2.1 The context}

The authors, who were also the teachers, adopted the R2L methodology on an English for General Purposes course for adults at an English Language Centre at an Australian University. Such courses are referred to as General English (GE) at the centre. The learners in the class were from the following countries: Taiwan, Japan, China, Saudi Arabia and Colombia. They were assessed by the centre as intermediate learners at B1 on the Common European Framework of Reference (CEFR). The learners were developing their English language proficiency for a range of reasons, from meeting entry requirements for pathway courses into the university, to supplementing previous English studies in their own countries, to improving their future employability. The class followed a course designed to develop general language proficiency in 'everyday' social domains.

The writing syllabus included knowledge genres such as recounts and expositions (arguing for one point of view). Interestingly, these genres differ in 
emphasis from school knowledge genres in their registers as they are taken from 'everyday' adult domains (e.g. writing an email to enquire about a work conference), rather than the more technical fields of academic domains (e.g. a classifying report on marine mammals). They tend to foreground social activities relevant to the adult learners and they are selected because they anticipate the future social practices in which the learners will engage when using English outside the classroom. These are anticipated to be non-educational contexts in which adults use language. For example, the written recount from the syllabus was modelled as an adult retelling the events of a holiday to another adult.

\subsection{The research tools and data}

From our own training and education, we began this project as reflective practitioners. The reflective model (Wallace, 1991, p. 15) combines 'received knowledge' (i.e. the generally accepted disciplinary theories of language, teaching and learning that underpin teaching training courses) and previous experiential knowledge (i.e. from classroom experience) while recognizing the benefits of reflective practice. After planning and teaching a lesson using the R2L methodology, we reviewed our plans, materials, photographs of whiteboards, learners' writing and our experiences during the lesson. We then wrote down a summary and arranged a time to meet and discuss our experiences. This cycle allowed us to discuss strengths and weaknesses of lessons as well as unforeseen events. While reflective practice is essentially a private matter, this peer support was the first step in making this process public, beginning to bring our knowledge into the public realm. As practitioner research, we planned to share our experiences with other stakeholders (e.g. colleagues and peers in the TESOL community) and influence other research, professional practice and our own continuing professional development. To help us make sense of our classroom experiences, systematise our research and enable us to share our findings, we adopted a well-known model that is based on three simple questions: What? So what? Now what?

\subsection{What? So what? Now what?}

These simple and effective prompts gave our reflections and discussions a clear focus. This usually translated as:

What? $=$ the experience

So what? $=$ the significance of our experience (reflection \& theory)

Now what? = our next steps (challenges and opportunities that informed our next decisions)

When discussing our classroom experiences, we worked through these questions. We first described what happened and then discussed what had had an impact on us and our learners and why. We then identified what we wanted to do next. This involved reviewing and adapting our lesson plans for future use, talking about follow up lessons with our learners, summarising what we had learnt and recognising areas of knowledge and practice that we wanted to learn more about. Question prompts were useful in facilitating these discussions (University of Connecticut, n.d.). We have also used this model to guide our reflections (see Figure 3 below).

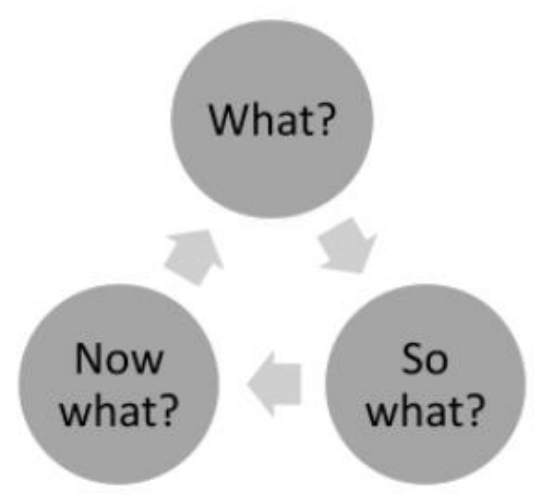

Figure 3: A reflection model developed by Rolfe et al (2001)

3. Findings and discussion: our experiences with key curriculum genres for teaching a recount genre for intermediate (B1) General English learners 
This section will describe how we taught the genre recount for intermediate (B1) General English learners.

\subsection{Planning: Analysing knowledge genres What?}

Firstly, we analysed this target genre: a brief exercise where we identified the general features and organisation of a recount. As outlined by Rose \& Martin (2012, p. 130), the purpose of a recount is to retell events. The purpose of each paragraph was also marked on our master copies. For example, paragraph one orientates the reader so it was important to highlight information that told the reader when the recount happened, where it happened and so on. Through our guidance, we expected our learners to recognise this key information during readings of the text because this key information also formed the basis of our learners' own recount.

So what? Analysing the genre was important because we could gain a deeper understanding of the text, on a macro-level (whole text) and micro-level (sentence). As a result, we felt more competent as teachers in the classroom and more able to support writing development. By taking the time to identify the key features of a genre, we were better able to make them salient and stand out to our learners. For example, we might ask questions such as 'What is the whole text about?' (a memory), 'What is the purpose of the first paragraph?' (to give background information), and 'What does this sentence tell us?' (when the event happened). Learners often commented that this analysis had given them more confidence to write. Therefore, this process not only contributed to our own professional knowledge of the genre but also to our learners' genre knowledge.

Now what? Analysing the genre presented some challenges and opportunities. One challenge was not allowing enough time to complete this step. Time restraints sometimes meant this step was skipped because it was one of the easiest steps to bypass. However, this resulted in us relying on our knowledge in the moment of teaching, causing feelings of unpreparedness and timing issues. By contrast, the more we were informed on the genre features prior to the lesson the more we were able to guide our learners effectively and confidently.

\subsection{Preparing for Reading}

What? Preparation was key to helping learners' writing development. To begin with, choosing an appropriate reading passage was important because it provided either content or language that learners required in their writing. The recount chosen for this intermediate (B1) General English class was based on a memorable holiday. As mentioned in Section 1.3, the first step was to paraphrase the sentence so learners could engage in and understand the sentence. For example, we prepared the first sentence as follows (Table 3.1):

Table 3.1

\begin{tabular}{|l|l|}
\hline Model & $\begin{array}{l}\text { When I was } 5 \text { years old, I went to Hawaii } \\
\text { with my family for ten days. }\end{array}$ \\
\hline Script & $\begin{array}{l}\text { This sentence tells us that the writer went on } \\
\text { a holiday when she was a child to Hawaii (an } \\
\text { island near America) with her mother and } \\
\text { father for about one week. }\end{array}$ \\
\hline
\end{tabular}

Then, we decided on the key words we wanted to focus on. How we decided on the key words depended on our learners' needs. In this example, our primary focus was on content words which could later be substituted. For example, '5 years old' could be substituted in the learners' recounts with '10 years old' or 'a teenager'. We prepared these key words as follows (Table 3.2):

\section{Table 3.2}

\begin{tabular}{|l|l|}
\hline $\begin{array}{l}\text { Key } \\
\text { words }\end{array}$ & Script to cue key words \\
\hline $\begin{array}{l}5 \text { years } \\
\text { old }\end{array}$ & Which words describe a young age? \\
\hline
\end{tabular}

The final preparation is in the elaboration of the key words. Elaborations extend learners' knowledge about new language and content. For example, we 
chose to elaborate the first key words (5 years old) as follows (Table 3.3):

\section{Table 3.3}

\begin{tabular}{|l|l|}
\hline $\begin{array}{l}\text { Key } \\
\text { words }\end{array}$ & Script to elaborate on key words \\
\hline $\begin{array}{l}5 \text { years } \\
\text { old }\end{array}$ & $\begin{array}{l}\text { Do these key words tell us when the } \\
\text { event happened? (Yes) } \\
\text { Do you remember a holiday when you } \\
\text { were 5 years old? }\end{array}$ \\
\hline
\end{tabular}

All this preparation required careful consideration, especially in the area of grading language. How many sentences we scripted depended on lesson aims. However, as this was a timeconsuming component not only for planning but also for implementing, we often only scripted about 5-8 sentences (or one paragraph). The planning took approximately 20 minutes.

So what? Preparing the script was vital for the success of the lesson because it provided essential support for learners' writing development. In the early stages, due to a last-minute decision, one of us attempted a detailed reading without a script. However, it was evident that a script was essential for helping learners to understand the reading passage. For example, doing the detailed reading stage without a script caused the teacher to hesitate or search for the right words to use. Consequently, learners became confused or disengaged. Collaborating was one solution to lightening the load of this time-consuming step. This worked particularly well if we were both on the same writing course.

Now what? Learning how to prepare a script was a process. One challenge was that we needed to remain consistent, particularly when cueing the key words. For example, on the first attempt at developing the script it was easy to become confused between the focus on word meanings and word functions. With the key words ' 5 years old', we could focus on the meaning (an age) or the function (to describe when the event happened). Therefore, we found consistency was integral, especially to support the learners later during the joint rewriting stage. In other words, a well- developed script encouraged noticing of essential elements for good writing skills.

\subsection{Detailed Reading (Scaffolding reading} texts)

What? By actualising the well-prepared script in the classroom, we could have valuable interactions which developed our learners' understanding of the text and key language. We systematically went through the script, prompting and guiding the interactions. These interactions were an example of guiding learners through dialogue in the context of shared experience (Martin, 1999/2012). Following is a sequence of how our script for one key word unfolded (Table 3.4):

\section{Table 3.4}

\begin{tabular}{|l|l|l|}
\hline \multicolumn{2}{|c|}{ When I was 5 years old, I went to Hawail with my } \\
family for ten days.
\end{tabular}




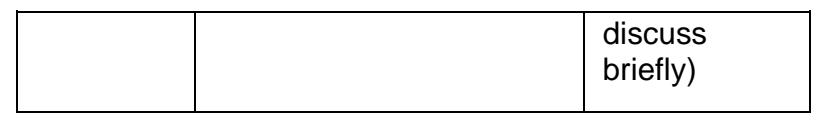

The sequence above was repeated for each key word and sentence. From this short excerpt, it is easy to see that we had the heaviest talking load. While we sometimes found this uncomfortable due to our training in communicative language teaching, we knew it was necessary to provide explicit guidance to our learners.

So what? This role as guide in the detailed reading stage was important because it gave us a key insight into our learners' prior knowledge, especially relating to lexical knowledge. As the learners responded to us, we could adjust the script slightly to address learner needs. For example, if we could not elicit the key phrase ' 5 years old' as per the script, we could add another prompt such as 'It's 3 words' or 'It's an age when children start school'. This support was crucial in ensuring that all learners could participate and successfully complete the tasks.

Furthermore, by asking learners to highlight these key words, we increased the salience. Richard Schmidt $(1990,2001)$ suggests language items need to be salient so that learners can notice them and henceforth, process and use them. This noticing, processing and application of key language items was strikingly evident in the learners' writing, both in the joint rewriting and individual writing. For example, almost all of our learners began their recount with 'When I was + an age'.

Secondly, one thing that was surprising was learners' fragmented understanding of the text. Reading comprehension tasks in course materials can often focus on testing the learners' reading skills rather than teaching the skills. To illustrate, it was clear that some learners had little understanding of the meaning and function of linking words. As a result, they had often misused linking words in writing (e.g. using 'also' instead of 'but' to show contrast).

Now what? Undoubtedly, the detailed reading stage was paramount in developing our learners' writing skills. However, this stage also presented one of the biggest challenges: pacing. Because of the nature of the detailed reading, high Teacher Talking Time (TTT) was inevitable. Therefore, in terms of a classroom procedure, it was important to maintain an appropriate learning pace by neither rushing students nor overdoing it with the TTT.

High Teacher Talking Time can often sit uncomfortably with teachers, especially to those who prefer taking a more communicative or inductive approach to teaching, as was the case for one of us. A change to our usual teaching style meant we had to reflect more. That is, it was important to make this stage feel comfortable in order to maintain interest in this methodology. We explored different ways to implement the detailed reading after each lesson. For example, in the first implementation we asked learners to write the key words on the whiteboard. In the second implementation, we highlighted the key words on a PowerPoint by omitting the text around them. In another implementation, we combined the detailed reading and joint rewrite stages (i.e. one sentence at a time). Therefore, fine-tuning the detailed reading stage to suit our teaching style became a very dynamic process. However, this just demonstrated our personal reactions to this stage. It is important that the key principles remain the same. That is, the principle behind the detailed reading is to explicitly explain and guide learners through the language.

Despite the challenges, we also noticed great opportunities. Firstly, our learners demonstrated a much deeper understanding of the language after doing a detailed reading. This was evident in their writing. For example, learners used linking words more accurately. Secondly, the learners' fragmented understanding of the text was a critical insight and enabled us to evaluate their needs more precisely. Based on these needs, we could chose similar troublesome language items in subsequent detailed readings.

\subsection{Joint Rewriting}

What? Joint rewriting required high support and constant interaction between the teacher and class. Firstly, the teacher nominated a learner to write the highlighted key words of Sentence One on the whiteboard. This step was repeated for each sentence from the detailed reading. As only one learner could 
write at a time, keeping this step brief was key to maintaining learner engagement. The other learners copied this down. The example below shows how a learner would write the key words on the whiteboard, leaving a gap between each key word/s (Table 3.5):

Table 3.5

\begin{tabular}{|l|ll|}
\hline Sentence One & $\begin{array}{l}\text { When I was } 5 \text { years old, I went to Hawail with my } \\
\text { family for ten days. }\end{array}$ \\
\hline $\begin{array}{l}\text { Key words on } \\
\text { whiteboard }\end{array}$ & 5 years old Hawaii & ten days \\
\hline
\end{tabular}

Then, the teacher nominated individual learners to rewrite one complete sentence on the whiteboard, using the key words. During this completion, we noticed that the interactional support between the nominated writer, teacher, and peers enabled the writer to produce a sentence at a level beyond their present competence. For example, if a nominated writer had written '5 year old', a peer might have prompted him/her to write 'years'. Alternatively, the teacher might have asked the writer to check his/her spelling. These constant interactions were invaluable because they not only revealed emergent language needs but also pushed learners to go beyond their present level.

A variation to rewriting the original text was to rewrite the text with substitutions. For example, in one of our intermediate (B1) General English classes, the learners rewrote Sentence One as follows (Table 3.6):

\section{Table 3.6}

\begin{tabular}{|l|l|}
\hline Sentence One & $\begin{array}{l}\text { When I was } 5 \text { years old, I } \\
\text { went to Hawail with my } \\
\text { family for ten days. }\end{array}$ \\
\hline $\begin{array}{l}\text { whole-class rewrite } \\
\text { with substitutions }\end{array}$ & $\begin{array}{l}\text { When I was 10 years old, I } \\
\text { went to Disneyland for } \mathbf{3} \\
\text { days. }\end{array}$ \\
\hline $\begin{array}{l}\text { small-group rewrite } \\
\text { with substitutions }\end{array}$ & $\begin{array}{l}\text { When I finished high } \\
\text { school, I visited London } \\
\text { alone. }\end{array}$ \\
\hline
\end{tabular}

In the whole-class rewrite, one can see that the key words were substituted with new key words: '5 years old' changed to '10 years old'. In the small-group rewrite, learners took more risks: 'When I was 5 years old' changed to 'When I finished high school'. It was clear that the learners had processed the key words during the detailed reading stage and were able to effectively use them in their own rewrite.

So what? The joint rewrite stage was significant because it gave valuable insights into the learners' writing knowledge and gaps. The rewrites are reproduced in Table 3.7 below and they are followed by our reflections.

Table 3.7

\begin{tabular}{|l|l|l|l|l|}
\hline Model & $\begin{array}{l}\text { When I } \\
\text { was 5 } \\
\text { years old, }\end{array}$ & $\begin{array}{l}\text { I went to } \\
\text { Hawaii }\end{array}$ & $\begin{array}{l}\text { with } \\
\text { my } \\
\text { family }\end{array}$ & $\begin{array}{l}\text { for } \\
\text { ten } \\
\text { days. }\end{array}$ \\
\hline $\begin{array}{l}\text { Whole } \\
\text { class }\end{array}$ & $\begin{array}{l}\text { When I } \\
\text { was 10 } \\
\text { years old, }\end{array}$ & $\begin{array}{l}\text { I went to } \\
\text { Disneyland }\end{array}$ & $\begin{array}{l}\text { for 3 } \\
\text { days. }\end{array}$ \\
\hline $\begin{array}{l}\text { Small } \\
\text { Group }\end{array}$ & $\begin{array}{l}\text { When I } \\
\text { finished } \\
\text { high } \\
\text { school, }\end{array}$ & $\begin{array}{l}\text { I visited } \\
\text { London }\end{array}$ & alone. & \\
\hline
\end{tabular}

We observed that in the whole-class rewrite the changes were slight. For example, only the number changed in the time phrase: ' 5 years old' $\rightarrow$ '10 years old'. However, having had whole-class practice, learners began to show more confidence and they began to experiment with the language more in the small-group rewrite. For example, the time phrase became more complex, going from just replacing a number (5) to a whole chunk of language (finished high school). Learners went from changing just the place in the sentence (Hawaii $\rightarrow$ Disneyland) to changing the verb and place (went to Hawaii $\rightarrow$ visited London). Finally, learners did not simply replace the word 'family' in the chunk 'with my family'. Instead, they chose a more advanced word 'alone'. These transformations demonstrated that our learners had successfully processed the linguistic knowledge from the detailed reading.

Undoubtedly, the most significant insights came from hearing and seeing the learners' inner workings. For example, we could hear the nominated writer 'thinking' as they contemplated a word and we 
could hear his/her peers responding. A conversation often sounded similar to this:

Nominated writer: "Is that the spelling?"

Peer: 'You need an 's' after 'year'. '5 years old' not 'year'”.

This interaction between the nominated writer and a more capable peer aided learning. As (Martin, 1999) asserts, language develops with guidance through interaction through the shared context of learning activities in the classroom. This was certainly the case in our classes. That is, the nominated writer could do more than they were capable of doing independently when they interacted with a more competent peer or teacher. Furthermore, because learners did not rewrite alone, learning took place at each point they encountered a linguistic gap. They were able to improve their writing through advice and correction. This feedback was crucial, not only to improve writing but also to build confidence.

In addition, as teachers, we could see the learners' writing and interactions unfolding in front of us and in turn we could notice their limitations. Being able to work with these emergent needs in the moment of writing made the guidance relevant to the learners. This relevancy aided noticing and encouraged learners to build on their existing knowledge. To experience this development was also rewarding for us, the teachers.

Now what? As mentioned above, joint rewriting had many opportunities such as pushing learners to the next level and making learning visible. However, we also had some challenges. The most significant one was learner engagement. Because only one writer could be nominated at one time, the other learners sometimes became disengaged, especially in larger classes. Some learners tended not to interact without being nominated, which became a challenging task for the teacher. Therefore, our role was not only to guide the learners but also to encourage them. Take for example our key words '5 years old'. An engagement challenge might unfold as follows (Table 3.8):

\section{Table 3.8}

\begin{tabular}{|l|l|l|}
\hline $\begin{array}{l}\text { Interaction } \\
\text { type }\end{array}$ & $\begin{array}{l}\text { Teacher as } \\
\text { guide and } \\
\text { encourager }\end{array}$ & $\begin{array}{l}\text { Engagement } \\
\text { challenge }\end{array}$ \\
\hline $\begin{array}{l}\text { Teacher } \rightarrow \\
\text { class }\end{array}$ & $\begin{array}{l}\text { "How do you spell } \\
\text { that?" }\end{array}$ & $\begin{array}{l}\text { the class does } \\
\text { not respond }\end{array}$ \\
\hline $\begin{array}{l}\text { Teacher } \rightarrow \\
\text { nominated } \\
\text { writer }\end{array}$ & $\begin{array}{l}\text { "What do you } \\
\text { think?" }\end{array}$ & $\begin{array}{l}\text { the nominated } \\
\text { writer thinks }\end{array}$ \\
\hline $\begin{array}{l}\text { Teacher } \rightarrow \\
\text { class }\end{array}$ & $\begin{array}{l}\text { "Can anyone help } \\
\text { him?" }\end{array}$ & $\begin{array}{l}\text { the class does } \\
\text { not respond }\end{array}$ \\
\hline $\begin{array}{l}\text { Teacher } \rightarrow \\
\text { learner }\end{array}$ & $\begin{array}{l}\text { "John, what do } \\
\text { you think? How } \\
\text { do you spell those } \\
\text { key words?" }\end{array}$ & $\begin{array}{l}\text { the learner } \\
\text { contemplates but } \\
\text { does not answer }\end{array}$ \\
\hline
\end{tabular}

This amount of encouragement to elicit an answer demonstrates that outward signs of engagement can be limited. However, that is not to say the learners were not engaged during our classes. We knew learners were somewhat cognitively engaged as we could see evidence of learning in their writing development. Nevertheless, a lack of interaction with the interlocutor (the teacher) sometimes created issues with lesson timings, drawing this stage out longer than anticipated. To counter this, we often reduced the number of sentences we explored in the detailed reading stage. We also became much more selective with the text as it had to address all our needs to meet the lesson aims.

\subsection{Independent writing}

What? Independent writing is the final stage of developing writing. Many writing materials move straight to this step. Whether learners write it at home or in the class, the teachers' guidance is often minimal to nil. However, by going through the process of the Reading to Learn program, we noticed our learners launching into writing feeling confident and prepared. This was evident by the lack of hesitation and constant editing during independent writing. Qualitative feedback also indicated that learners felt their writing skills had developed. Comments such as "That was really good" and "I never knew that... but now I know" were frequent. 
So what? The main reflection was that the earlier stages were important for building confidence and linguistic knowledge to write independently. With the support and guidance during the detailed reading and joint rewriting, learners developed control of their writing skills. In the following excerpts, we recognised more control in the learners' independent writing skills and less inclusion of writing errors or clichés (Table 3.9):

\section{Table 3.9}

\begin{tabular}{|l|l|}
\hline Model & $\begin{array}{l}\text { When I was } 5 \text { years old, I went to Hawaif } \\
\text { with my family for ten days. }\end{array}$ \\
\hline $\begin{array}{l}\text { Learner } \\
1\end{array}$ & $\begin{array}{l}\text { When I was } \mathbf{1 6} \text { years old, I went to Feng } \\
\text { Yang alone for } \mathbf{3} \text { days. }\end{array}$ \\
\hline $\begin{array}{l}\text { Learner } \\
2\end{array}$ & $\begin{array}{l}\text { When I was } \mathbf{1 3} \text { years old, I went to } \\
\text { Universal Studio Japan with my friend. }\end{array}$ \\
\hline $\begin{array}{l}\text { Learner } \\
3\end{array}$ & $\begin{array}{l}\text { When I was } \mathbf{1 8} \text { years old, I went to } \\
\text { Maldives for } \mathbf{7} \text { days. }\end{array}$ \\
\hline
\end{tabular}

As in the model recount, learners consistently showed when the event happened, where they went, who they went with and for how long (indicated in bold in Table 3.5). While not all learners grasped the process as efficiently as others, it was clear that many learners did reflect on the language they learned from the detailed reading and joint rewriting and could transfer this acquired linguistic knowledge to their writing output. Therefore, on the whole, we felt that this methodology was a success in class.

Now what? The key outcome of this final stage was that we encouraged independent writing skills. We encouraged this independence by first ensuring our learners understood the reading text and then by helping them to write a new text. They wrote better because they had the support. The interactions formed a crucial part of this support structure. Although we sometimes had reservations implementing this new methodology, we could not deny that it worked. The opportunities outweighed any challenges that we experienced. For this reason, we continue to support writing development through detailed reading and joint rewriting.

\section{Reviewing the impact on learner writing}

The R2L program is a framework with prescriptive stages to develop learners' writing. These key stages, as outlined in Section 3, had a significant impact on the learners' writing output. Specifically, developing the learners' genre knowledge (3.1), identifying and elaborating on key words in the detailed reading (3.3), and rewriting a text jointly (3.4) were paramount in supporting writing development.

Developing the learners' genre knowledge enabled learners to identify key features of a genre. As a result, the learners demonstrated their learning with texts that were well-organised and sentences that were purposeful (e.g. sentences that indicated the time of the event or the place of the event).

Identifying and elaborating on key words encouraged learners to understand language more deeply, not only on a semantic level but also on a functional level. Their writing was more accurate in that we did not notice the inclusion of many random or nonsensical words, which was often the case in earlier writing attempts without the R2L program.

Rewriting a text jointly had a significant impact on the learners' writing development. Through real-time feedback, writers could push themselves to the next level, improving their writing as they encountered each linguistic gap. Learners' emergent language needs were addressed immediately through crucial interactions between the teacher and peers. Consequently, this not only aided the writer to improve their accuracy but also gave the whole class an opportunity to learn from the advice.

To us, it was clear that these three key stages (Preparing befor reading, Detailed Reading, and Joint Rewriting) supported our learners to write independently with more confidence and accuracy. We achieved this by guiding them through a text in carefully planned stages which encouraged deeper understanding of genre and language. An often lonely task for learners became an opportunity to demonstrate 
writing skills with confidence in their independent writing.

\section{Conclusion}

Practitioner research can be seen as a state of mind (Hamilton, 2006, p. 16), as well as an activity that offers numerous benefits to practitioners, their organisations and the associated field of research. For example, discussing the benefits of the three-year Practitioner-Led Research Initiative (PLRI), researchers noted four areas of benefit to the practitioner researchers: fresh perspectives; professional development; a boost to status alongside increased internal visibility within their organisations; and the usefulness of the findings (Hamilton et al, 2007, p. 21). We also recognise these benefits from our experiences with this project. Practitioner research has encouraged reflexivity and reflection but, more than this, it has driven the development of professional practice through systematic investigation and the sharing of results. It has also led to the strengthening of the relationship between theory and practice, and we have gained first-hand experience of the research process. The experience has led to our greater engagement with research to the benefit of our professional practice.

Through our project, we have certainly engaged with genre pedagogy at a greater depth than if we had simply read an article about it. This relationship is reciprocal, and traditional researchers can gain greater understanding of practitioners, their work and their professional practices through practitioner research. This can inform their own research and ensure it is relevant to the needs and interests of practitioners. While practitioner research presents challenges and additional workload demands for professionals, it also offers rewards that make the endeavour worthwhile.

We also identify with all the benefits of teacher research identified in Table 1 above. However, the top three benefits from our own experiences are as follows. Firstly, it has promoted collaboration between teachers. We discussed our plans and lessons in much greater depth than we otherwise would have done and our plans, lessons and reflections benefitted from this. Secondly, it gave us greater insight into our own practices. Thoroughly analysing model texts and carefully designing classroom interactions using the tools from the R2L program has greatly increased our awareness of our own practices and allowed us to change and reshape them in pursuit of greater learning outcomes for all our learners. Thirdly, it has encouraged flexibility in teaching. Before engaging with R2L methodology, we were guided by our training in communicative language teaching that emphasises student-centredness as good practice and teachercentredness as not. Our engagement with genre pedagogy has opened our minds to new possibilities in our teaching, revealing this distinction as a false dichotomy; as the above findings report, there are benefits to teachers providing clear guidance. A more nuanced approach, sensitive to the affordances provided by the roles of teachers and learners in the language classroom, has increased our flexibility in teaching.

Applying R2L methodology in our context presented us with both challenges and opportunities. The main challenges we faced included finding time in our busy work schedules to analyse, plan and reflect on our classroom experiences. More specifically, planning the classroom interactions and then using this plan to manage these classroom interactions was perhaps the biggest challenge we faced. Overall, we are very pleased with the results. The focus on carefully analysing passages and planning classroom interactions, based on these analyses and our learners' needs, has made us more aware of and able to work with learners' emerging language. As busy teachers, we had to maintain a focus on the classroom while also engaging with the R2L methodology. Planning, reflecting on and discussing our R2L lessons together gave us a way to navigate our way through preparing and teaching writing lessons.

The combination of the R2L methodology and the support we gave each other helped us find a path through the tricky terrain of changing our classroom practices. The Cambridge English Trainer 
Framework recognises that "[i]t takes time and effort for teachers to change their practice" (Cambridge English, 2016, p.3). While it certainly took time and effort for us to change our practice, we believe that it has been a worthwhile endeavour for us as teachers and for our learners. Through persistence and commitment, and with the help of peer support, we greatly benefitted from our position as classroom practitioners engaged with research. Missing in action and lost in thought is hard work but our insights and experiences have proved extremely valuable for our professional development. 


\section{References}

Allwright, D. (1997). Quality and sustainability in teacherresearch. TESOL Quarterly, 31(2), 368-370.

Allwright, D., \& Bailey, K. (1991). Focus on the language classroom. Cambridge: Cambridge University Press.

Allwright, D., \& Hanks, J. (2009). The developing language learner: An introduction to Exploratory Practice. London: Palgrave Macmillan.

Barton, D. (2005). Teacher researchers. Reflect, (2), 33.

Borg, S., \& Sanchez, H. (2015a). Key issues in doing and supporting language teacher research. In S. Borg \& $\mathrm{H}$. Sanchez (Eds.), International Perspectives on teacher research (pp.1-13). Basingstoke, UK: Palgrave Macmillan.

Borg, S. \& Sanchez, H. (2015b). Teacher research: Looking back and moving forward. In S. Borg \& H. Sanchez (Eds.), International Perspectives on teacher research (pp.185-193). Basingstoke, UK: Palgrave Macmillan.

British Association of Applied Linguists (BAAL) (2016). The British Association for Applied Linguistics: Recommendations on good practice in Applied Linguistics. Retrieved from

http://www.baal.org.uk/goodpractice_full_2016.pdf

Burns, A. (2009). Doing action research in English language teaching: A guide for practitioners. Routledge.

Cambridge Assessment English (2016). Cambridge English Trainer Framework. Retrieved from https://www.cambridgeenglish.org/Images/297312cambridge-english-trainer-framework.pdf

Council of Europe. 2001a. Common European Framework of Reference for Languages: Learning, teaching, assessment. Cambridge: Cambridge University Press.

Christie, F. \& Martin J. R. (Eds.) 1997. Genre and Institutions: social processes in the workplace and school. London: Cassell (Open Linguistics Series).

Christie, F. 2002. Classroom Discourse Analysis. London: Continuum.

Cope, W. \& M. Kalantzis (Eds.) 1993. The Powers of Literacy: a genre approach to teaching literacy. London: Falmer \& Pittsburgh: University of Pittsburgh Press.

Hamilton, M. (2006). Practitioner research: just a fling or a long-term relationship? Reflect, 6, 14-18.

Hamilton, M., Davies, P., \& James, K. (2007).

Practitioners leading research. London: NRDC.

Martin, J. R. (1999). Mentoring semogenesis: 'genrebased' literacy pedagogy. In F. Christie (ed.), Pedagogy and the Shaping of Consciousness: Linguistic and Social Processes, (pp. 123-155). London: Cassell (Open Linguistics Series). (Reprinted in 2012 in Z. Wang (ed.).
Language in Education, Vol. 7 in the Collected Papers of J. R. Martin (pp. 224-54). Shanghai: Shanghai Jiao Tong University Press).

Martin, J. R. (2009). Genre and language learning: A social semiotic perspective. Linguistics and Education, 20(1), 10-21.

Martin, J.R. \& Rose, D. (2007). Working with Discourse: meaning beyond the clause. London: Continuum

Martin, J.R. \& Rose, D. (2008). Genre Relations: mapping culture. London: Equinox.

Rolfe, G., Freshwater, D., Jasper, M. (2001) Critical reflection in nursing and the helping professions: a user's guide. Basingstoke: Palgrave Macmillan.

Rose, D. (2008). Writing as linguistic mastery: The development of genre-based literacy pedagogy. In R. Beard, D. Myhill, J. Riley and M. Nystrand (eds.). Handbook of writing development (pp. 151-66). London: Sage.

Rose, D. (2011) Genre in the Sydney School. In J. Gee and M. Hanford (eds.). The Routledge handbook of discourse analysis (pp. 209-225). London: Routledge.

Rose, D. (2015). New developments in genre-based pedagogy. In C. A. MacArthur, S. Graham and J. Fitzgerald (eds.), Handbook of writing research, (pp.22742). New York: Guildford.

Rose, David. (2017). Languages of Schooling: embedding literacy learning with genre-based pedagogy. European Journal of Applied Linguistics, 5(2), 1-31.

Rose, D (2018) Reading to learn: Accelerating learning and closing the gap. Sydney: Reading to Learn. http://readingtolearn.com.au

Rose, D. (2020) Building a pedagogic metalanguage I: Curriculum genres. In J. R. Martin, K. Maton \& Y. J. Doran, (Eds.)., (2020). Accessing Academic Discourse: Systemic Functional Linguistics and Legitimation Code Theory. Routledge.

Rose, D. \& J. R. Martin 2012. Learning to Write, Reading to Learn: Genre, knowledge and pedagogy in the Sydney School. London: Equinox

Rothery, J. (1994). Exploring literacy in school English (Write it right resources for literacy learning), Sydney: Metropolitan East Disadvantaged School Program.

Rothery, J. (1996). Making changes: developing an educational linguistics. In R. Hasan \& G. Williams (Eds.) Literacy in Society (pp. 86-123). London: Longman.

Schmidt, R. W. (1990). The Role of Consciousness in Second Language Learning. Applied Linguistics, 11(2), $129-158$

Schmidt, R. W. (2001). Attention, cognition and second language instruction. In P. Robinson (Ed.), Cognition and second language instruction (pp.3-32). Cambridge: Cambridge University Press. 
Schön, D. (1983) The reflective practitioner. Aldershot, UK: Ashgate.

Shulman, L. (1987a). Further Comment: Sounding an Alarm: A Reply to Sockett. Harvard Educational Review, 57(4), 473-484.

Rolfe, G., Freshwater, D., Jasper, M. (2001) Critical reflection in nursing and the helping professions: a user's guide. Basingstoke: Palgrave Macmillan.

University of Connecticut, Center for Excellence in Teaching and Learning (n.d.). What? So what? Now what? Model. Retrieved from https://cetl.uconn.edu/whatso-what-now-what-model/\#

van Lier, L. (1994). Forks and Hope: Pursuing understanding in different ways. Applied Linguistics, 15(3), 328-345.

Wallace, M. J. (1991). Training foreign language teachers: A reflective approach. Cambridge: CUP.

\section{COMO CITAR ESSE ARTIGO}

SCOTT, Andrew Glencairn; HAFENSTEIN, Tanja. Missing in action and lost in thought: a grassroots implementation of genre pedagogy by practitioner researchers in an English language classroom for adults. Signo, Santa Cruz do Sul, v. 46, n. 86, may 2021. ISSN 1982-2014. Disponível em: <https://online.unisc.br/seer/index.php/signo/article/view/15904>. doi:https://doi.org/10.17058/signo.v46i86.15904. 